lating $\phi$ from association constants obtained by whatever analytical technique. Comparing such calculated values with the experimentally measured $\phi$ values, discrepancies due to the neglected solute-solvent interactions might be revealed.

IVAN J. GAL Nuclear Sciences, Beograd, Yugoslavia

\title{
Synthesis of lead(II)titanate and related compounds with the perovskite structure
}

\author{
(Received 15 May 1972)
}

As PART of a solid state investigation of leadzirconate-titanate systems, different methods of synthesis are being used, such as heating of the well-mixed oxides [1], pyrolysis of amorphous organic precursors [2] and thermal decomposition of oxalate complexes [3].

After a successful synthesis of the ilmenite-structure compounds $\mathrm{FeTiO}_{3}, \mathrm{MgTiO}_{3}$ etc. and solid solutions thereof by thermal decomposition of the well-defined aquohexafluorotitanate complexes of the type $\mathrm{Fe}\left(\mathrm{H}_{2} \mathrm{O}\right)_{6} \mathrm{TiF}_{6}[4]$, the authors tried to apply the same method to the synthesis of compounds having the perovskite structure such as $\mathrm{PbTiO}_{3}$ via the complex $\mathrm{Pb}\left(\mathrm{H}_{2} \mathrm{O}\right)_{3} \mathrm{TiF}_{6}$. The principle of the method is given by the stoichiometric equations,

$$
\begin{gathered}
\mathrm{PbCO}_{3}+\mathrm{H}_{2} \mathrm{TiF}_{6}=\mathrm{Pb}\left(\mathrm{H}_{2} \mathrm{O}\right)_{3} \mathrm{TiF}_{6}[5] \\
\mathrm{Pb}\left(\mathrm{H}_{2} \mathrm{O}\right)_{3} \mathrm{TiF}_{6}=\mathrm{PbTiO}_{3}+6 \mathrm{HF}
\end{gathered}
$$

After thermogravimetric analysis of the aquofluoro complex it appeared that normal heating in air resulted in a mixture of $\mathrm{PbTiO}_{3}, \mathrm{PbF}_{2}, \mathrm{PbO}$ and $\mathrm{TiO}_{2}$. Therefore slow decomposition in nitrogen, nitrogen/steam and nitrogen/hydrogen/steam atmospheres was applied which, however, also resulted in contaminated $\mathrm{PbTiO}_{3}$ residues. But it was found that heating in air only, using a very slow heating program, to prevent evaporation of $\mathrm{TiF}_{4}$ at $284^{\circ} \mathrm{C}$, does result in pure $\mathrm{PbTiO}_{3}$.

An example of such a heating program is: $2 \mathrm{hr} 250^{\circ} \mathrm{C}, 2 \mathrm{hr} 300^{\circ} \mathrm{C}, 2 \mathrm{hr} 400^{\circ} \mathrm{C}, 8-16 \mathrm{hr} 550^{\circ} \mathrm{C}$, $\frac{1}{4} \mathrm{hr} 600^{\circ} \mathrm{C}, \frac{1}{4} \mathrm{hr} 700^{\circ} \mathrm{C}, \frac{1}{2} \mathrm{hr} 800^{\circ} \mathrm{C}$. It is noticed that heating at lower temperatures and at $550^{\circ} \mathrm{C}$ is carried out for a relative long period. Care has to be taken that the synthesis of the $\mathrm{Pb}\left(\mathrm{H}_{2} \mathrm{O}\right)_{3} \mathrm{TiF}_{6}$ leads to a pure product. In preparing an aqueous solution of $\mathrm{H}_{2} \mathrm{TiF}_{6}$ by dissolving $\mathrm{TiO}_{2}$ in aqueous $42 \% \mathrm{HF}$ on a hot waterbath it is advisable to add an excess of $\mathrm{TiO}_{2}$ in order to prevent a precipitate of $\mathrm{PbF}_{2}$ in the next step due to the presence of unreacted $\mathrm{F}^{-}$-ions. A less than equational amount of solid $\mathrm{PbCO}_{3}$ added to the filtered $\mathrm{H}_{2} \mathrm{TiF}_{6}$ solution, dissolves with effervescence, at the same time giving a white precipitate of $\mathrm{Pb}\left(\mathrm{H}_{2} \mathrm{O}\right)_{3} \mathrm{TiF}_{6}$, which can be washed with acetone. It was found that solutions of lead nitrate or acetate used in place of solid lead carbonate did not give as good results, because contamination by extra lead ions occurred. The reason might be that $\mathrm{Pb}\left(\mathrm{H}_{2} \mathrm{O}\right)_{3} \mathrm{TiF}_{6}$ is easily hydrolysed in a too great amount of water and/or that nitrate and acetate give adducts with the fluorotitanate.

1. W. R. Bratschun, J. Am. ceram. Soc, 46, 141 (1963).

2. C. Marcilly, P. Courty and B. Delmon, J. Am. ceram. Soc. 53. 56 (1970).

3. Y. Matsuo and H. Sasaki, J. Am. ceram. Soc. 49, 229 (1966).

4. P. J. Gellings, K. A. de Jonge and G. M. H. van de Velde, Chem. Ind. 1433 (1971).

5. P. Engelskirchen, Diss. Berlin Techn. Hochschule, 25 (1903). Gmelins Handbuch der Anorganischen Chemie, Pb, C4, p. 1391, (Edited by H. Bitterer). Verlag Chemie, Weinheim (1971). 
Analysis of the products showed:

$\mathrm{Pb}\left(\mathrm{H}_{2} \mathrm{O}\right)_{3} \mathrm{TiF}_{8}: \mathrm{Pb} 49 \cdot 10 \%$ (gravimetric as chromate), $\mathrm{Ti} 11 \cdot 40 \%$ (gravimetric as cupferronate), (theoretical Pb 48.97\%, Ti 11.32\%).

$\mathrm{PbTiO}_{3}: \mathrm{Pb} 68 \cdot 20 \%$ (gravimetric as lead sulphate after melting with potassium pyrosulphate [6]). Ti 15.96\% (gravimetric as $p$-hydorxyphenylarsonate), (theoretical $\mathrm{Pb} 68 \cdot 36 \%$, Ti $15 \cdot 80 \%$ ). Found by $\mathrm{X}$-ray fluorescence analysis: $\mathrm{Pb} 68.0 \%$, Ti $16.0 \%$.

In the table the $\mathrm{X}$-ray diffraction pattern of $\mathrm{PbTiO}_{3}$ obtained with $\mathrm{CuK} K_{\alpha}$-radiation in a diffraction spectrometer Philips PW 1320/1310 is compared with that given in the X-ray powder data file, card no. 6-0452 [7]. There is complete correspondence, which indicates that the used method yields pure $\mathrm{PbTiO}_{3}$.

Table 1. Comparison of X-ray diffraction patterns

\begin{tabular}{rrrrr}
\hline \multicolumn{3}{c}{ ASTM 6-0452 } & \multicolumn{2}{c}{ This work } \\
$h k l$ & $d(\AA)$ & \multicolumn{1}{c}{$l / I_{l}$} & $d(\AA)$ & Intensity \\
\hline 001 & $4 \cdot 150$ & 26 & $4 \cdot 149$ & 24 \\
100 & 3.899 & 49 & 3.897 & 47 \\
101 & $2 \cdot 842$ & 100 & $2 \cdot 846$ & 100 \\
110 & $2 \cdot 758$ & 52 & $2 \cdot 756$ & 49 \\
111 & $2 \cdot 297$ & 40 & $2 \cdot 301$ & 38 \\
002 & $2 \cdot 076$ & 15 & $2 \cdot 074$ & 13 \\
200 & 1.950 & 32 & 1.955 & 33 \\
102 & 1.833 & 13 & 1.829 & 11 \\
201 & 1.765 & 10 & 1.767 & 8 \\
210 & 1.744 & 11 & 1.748 & 10 \\
112 & 1.6581 & 19 & 1.6592 & 21 \\
211 & 1.6075 & 42 & 1.6090 & 39 \\
\hline
\end{tabular}

Acknowledgements - The authors wish to thank Mr. J. Th. Klein Elhorst and Miss M. M. A. Perik for performing the experiments and analyses. This investigation was supported in part by the Netherlands Foundation of Chemical Research (S.O.N.) with financial aid from the Netherlands Organisation for the Advancement of Pure Research (Z.W.O.).
Laboratory of Inorganic Chemistry
G. M. H. VAN DE VELDE
and Materials Science
U. SPITSBERGEN
Department of Chemical Engineering
P. J. GELLINGS

Technical University Twente

Enschede

Netherlands

6. I. M. Kolthoff, E. B. Sandell, E. J. Meehan and S. Bruckenstein, Quantitative Chemical Analysis, p. 1112, 4th Edn. MacMillan, London (1969).

7. $X$-ray Powder Data File. ASTM Special Technical Publication 48-J, Philadelphia (1960). 